\title{
Age Cohort
}

National Cancer Institute

\section{Source}

National Cancer Institute. Age Cohort. NCI Thesaurus. Code C71550.

Individuals in a study considered as a group based on age. 